\title{
ENTREVISTA COLÔNIAS, METRÓPOLES: UM ANTROPÓLOGO E SUA ANTROPOLOGIA
}

Adam Kuper

Adam Kuper é mais conhecido no Brasil por seus trabalhos sobre a antropologia britânica, de claro recorte histórico e de tom, ao mesmo tempo, crítico e irônico. Seu livro Antropólogos e Antropologias, traduzido para o português pouco após ser publicado, tornou-se um clássico em nossos cursos de graduação, assim como vem ocorrendo com The Invention of Primitive Society nos cursos de pós-graduação. Menos conhecida é sua produção propriamente etnográfica, baseada em pesquisas de campo na África e na Jamaica. Muitos ignoram, ademais, que Adam Kuper não é e não se vê exatamente como um antropólogo britânico. Ele nasceu na África do Sul e lá foi criado no período de consolidação do regime segregacionista. Nesta entrevista, exploramos as conexões entre a história social e política daquele país e o desenvolvimento intelectual da antropologia, a partir da perspectiva de um de seus filhos e autores.

Em agosto de 1999, Adam Kuper, professor da Brunel University, esteve no Brasil a convite do Programa de PósGraduação em Antropologia Social (Museu Nacional, UFRJ), onde proferiu uma série de conferências sobre seu recémlançado livro Culture: The Anthropologists' Account. Na ocasião, concedeu esta entrevista a C. Fausto e F. Neiburg.

\section{Fausto}

Podemos começar pela África do Sul, falando sobre antropologia sul-africana e o início de sua própria carreira como antropólogo.

\section{Kuper}

A antropologia desenvolveu-se, na África do Sul, muito ligada às questões políticas locais. Essa antropologia foi muito importante para a definição de pelo menos parte da agenda da moderna antropologia social britânica, através de Radcliffe-Brown, que lecionou durante muitos anos na África do Sul e estabeleceu a primeira cadeira de antropologia no país; através de Malinowski, que fez visitas à África do Sul, e de muitos alunos seus que se envolveram com o país; e através dos antropólogos sulafricanos que migraram para a GrãBretanha. Mas há também uma segunda história, pouco conhecida fora da África do Sul, que é a história da antropologia africânder, favorável à segregação racial e que produziu muitos dos suportes científicos e institucionais para o programa do apartheid. Assim, quando eu era aluno de graduação na África do Sul, havia esses dois tipos de antropologia. Uma delas é muito conhecida, muito cosmopolita, muito ligada à vida acadêmica britânica; a outra é essa antropologia africânder, desconhecida fora da África do Sul, mas muito poderosa dentro dela. Nas universidades de língua inglesa, a antropologia que estudávamos era de oposição, produzida como crítica ao apartheid e à antropologia que lhe servia de base. Enquanto es- 
ta última era romântica e primitivista, aquela insistia em tratar a África do Sul como uma única sociedade, em rápida transição. Os seus objetos etnográficos mais característicos eram coisas como a imigração de trabalhadores, as religiões mistas cristãs-africanas, a urbanização, e assim por diante.

\section{Neiburg}

Foi nesse contexto intelectual que você se formou?

\section{Kuper}

Eu estudei antropologia durante dois anos na África do Sul, como parte do curso de história. Em 1962, deixei o país e fiquei nove meses em Paris, depois fui para Cambridge como estudante de doutorado. Assim, boa parte de minha formação antropológica foi feita fora da África do Sul, mas foi a minha experiência lá que me fez querer ser antropólogo, e foi a situação da antropologia na África do Sul que me forneceu o modelo para os tipos de problemas e abordagens teóricas pelos quais me interessei. É claro que havia ainda o fato de a minha tia, Hilda Kuper, ser antropóloga e aluna de Malinowski. Quando eu tinha dezoito anos, ela me levou para um trabalho de campo na Suazilândia. Ela era péssima motorista e a Universidade de Natal não lhe deu permissão para usar o jipe da universidade na viagem à Suazilândia, alegando que ela sempre acabava se acidentando. Então ela disse, "bem, eu tenho um sobrinho de dezoito anos que é um excelente motorista". Então acabei indo, levando-a de carro para todo lado. Lembro de um encontro que foi particularmente importante para mim. Nós estávamos na aldeia da Rainha Mãe, onde minha tia havia feito bastante trabalho de campo, e sendo homem, eu não podia acompanhá-la, então fiquei no regimento que guardava a aldeia. O príncipe encarregado desse regimento, que tinha a minha idade e estava vestido com roupas clássicas dos Suazi, com lança e tudo, levou-me para a sua cabana. Os soldados levaram-lhe um recipiente com cerveja. Ele falava inglês fluentemente, pois como muitos dos aristocratas suazi, fora educado em uma escola pública inglesa. Em dado momento, ele me perguntou: "você acredita em feitiçaria?". Como eu tinha dezoito anos e havia acabado de deixar de acreditar em quase tudo, inclusive em feitiçaria, disse "não". Ele me olhou penalizado, e me disse algo que nunca esqueço e que sempre conto para meus alunos. Citou Hamlet: "There are more things in heaven and earth, Horatio/Than are dreamt of in your philosophy" ("Há mais coisas entre o céu e a terra, Horacio/Do que se sonha na sua filosofia"). Então fiquei pensando que era uma observação bem interessante diante da questão da feitiçaria e da racionalidade, especialmente partindo de um príncipe suazi. Nesse momento me ocorreu que talvez eu devesse me tornar antropólogo.

\section{Fausto}

Qual era, então, a correlação de forças entre a antropologia de orientação inglesa e a africânder?

\section{Kuper}

A antropologia africânder tinha o apoio do governo. Eram os alunos que se graduavam nas suas universidades que iam trabalhar como administradores nos Bantustãos, no serviço público, na educação. Eram eles que faziam o planejamento da administração pública. Institucionalmente, tinham controle absoluto, mas sabiam que internacionalmente eram párias, e tinham muita desconfiança em relação aos antropólogos das universidades de língua inglesa, 
que tinham reputação internacional, publicavam nos melhores periódicos, eram convidados para palestras em vários lugares. Havia uma tensão muito forte e o paradoxo de que quem tinha poder "em casa" não tinha capital cultural internacionalmente, e vice-versa. Mas os antropólogos de fala inglesa aos poucos foram saindo. Nem todos, pois alguns sentiam uma espécie de compromisso moral e nunca saíram. É o caso de Monica Wilson, que era filha, neta e acho que bisneta de missionários radicados no Transkei. Ela havia crescido lá e estava decidida a ficar.

\section{Neiburg}

Havia, naquela época, espaços institucionais para a antropologia nas universidades ou nas agências federais? Onde estavam os antropólogos?

\section{Kuper}

Depende do lado em que você estava. No lado de fala inglesa, não havia nenhuma oportunidade a não ser nas universidades de língua inglesa. As mais famosas eram a de Witwatersrand e a da Cidade do Cabo, e também a Universidade de Natal em Durban, onde minha tia lecionava. Havia também uma pequena universidade chamada Rhodes University, em Grahamstown, onde Phillip Mayer tinha uma equipe de pesquisa realizando estudos urbanos muito interessantes. Eram essas as universidades de língua inglesa. No caso da antropologia africânder, os estudantes formados acabavam no governo, porque os antropólogos africânderes tinham controle sobre os museus nacionais e provinciais. Foi interessante observar quando eles começaram a perder o referencial. Em 1982, fui à África do Sul em uma viagem de caráter privado. Lá, recebi um telefonema de um professor de etnologia da Rand Afri- kaans University. Todos os professores de etnologia nas universidades africânderes eram membros do Broederbond, a sociedade secreta que estava no coração do establishment africânder (Broederbond significa sociedade de irmãos em africâner). Recebi esse telefonema e o sujeito me disse: "sei que você está aqui para uma visita de cunho pessoal, mas se você tiver tempo, gostaria muito de conversar com você". Então fui visitá-lo. Foi a primeira vez que pus os pés nessa universidade Rand Afrikaans, que fora construída pelo governo a apenas dois quilômetros da minha própria, a Witwatersrand University, como forma de desafiar uma universidade liberal, esquerdista. Aquela universidade do apartheid parecia uma fortaleza. Entrar nela dava medo, a arquitetura era realmente fascista, fazia você se sentir minúsculo. Fui pelo corredor até a sala do professor de etnologia, e vi que do outro lado do corredor estava o Departamento de Pesquisas em Segurança Nacional. Ao encontrar o professor, ele começou a falar apaixonadamente, e quando percebeu que eu entendia africâner, passou a falar nessa língua e me contou a seguinte história: estava fazendo trabalho de campo em Gazankulu, uma região muito pobre; ele sabia falar muito bem a língua local. Quanto mais trabalho de campo fazia, mais percebia que o apartheid, longe de ajudar aquelas pessoas, era na verdade a principal causa de suas dificuldades. A sua primeira reação foi tentar explicar isso para as pessoas em Pretória. À medida que ele começou a falar com as pessoas, foi percebendo que elas não queriam ouvi-lo. Seus colegas começaram a isolá-lo, os seus filhos começaram a ter problemas com a direção da escola, as pessoas das agências do governo em Pretória começaram a insinuar que era melhor que ele tomasse cuidado. Com 
o tempo, as únicas pessoas com as quais continuava podendo conversar eram os dois colegas que estavam trabalhando com ele na pesquisa. Foi então que ele me telefonou, só porque queria desabafar.

\section{Fausto}

Quais eram as relações entre a antropologia africânder e a de orientação inglesa?

\section{Kuper}

Havia duas associações de antropologia na África do Sul, a de língua inglesa, à qual evidentemente também estavam afiliados os antropólogos negros, e a de língua africâner. E se alguém das universidades de língua africâner fosse a um congresso da Associação de língua inglesa, certamente teria problemas sérios com os seus superiores. Um ano depois da visita que contei, aquele antropólogo foi ao congresso da Associação de língua inglesa, e quando ele se levantou para apresentar seu trabalho, um funcionário do governo também se levantou e disse que ele não poderia fazê-lo, que o material era propriedade reservada do governo. Foi um momento muito dramático. Cerca de um ano depois, houve outro incidente. Eu estava na conferência da Associação de língua inglesa e havia um jovem antropólogo africânder, o que era muito incomum. Certa noite, sentei-me com ele para conversar, começamos a beber brandy sul-africano, que é muito bom e barato, e ele começou a me contar uma história. Ele nascera em Potchefstroom, uma pequena cidade africânder do Transvaal, famosa por ser muito calvinista. Contou-me sobre sua infância lá, sobre como foi para a universidade estudar antropologia, sobre as pesquisas que fez em Potchefstroom para o mestrado, junto à comunidade negra da cidade. À medida que os negros passaram a conhecê-lo melhor, eles contaram o seguinte: "nós tínhamos casas e lojas nessa parte da cidade, e o Conselho Municipal apropriou-se de tudo e nos expulsou. Um dos responsáveis foi o seu tio. Depois disso, ele comprou as terras a preços muito baixos". Ele foi verificar os arquivos do Conselho Municipal e viu que era tudo verdade; a partir daí começou a se questionar e a ganhar distanciamento. Foi muito interessante acompanhar o processo pelo qual esses antropólogos africânderes - muitos dos quais eram pessoas honestas, mas ao mesmo tempo muito provincianas e fechadas em uma comunidade extremamente leal, hierárquica e disciplinada foram aos poucos, um a um, chegando a uma ruptura.

\section{Fausto}

Você sabe qual a origem dessa sociedade secreta do Broederbond?

\section{Kuper}

Não estou bem certo. Surgiu quando o movimento nacionalista estava realmente começando, na década de 20 . Era uma rede de elites, dirigentes, ministros calvinistas, advogados, políticos, professores, que organizavam o movimento nacionalista. E quando chegaram ao poder, essa rede evidentemente passou a ser extremamente importante dentro do partido e do governo.

\section{Neiburg}

Quando foram fundadas as universidades na África do Sul?

\section{Kuper}

A Universidade da Cidade do Cabo é a única que foi criada ainda em fins do século XIX. A Universidade de Stellenbosch foi criada em 1910, eu creio, e a Universidade de Witwatersrand na dé- 
cada de 20. Minha mãe foi uma das primeiras alunas e acho que ela entrou lá dois anos depois que a universidade fora criada, em 1921 ou 1922.

\section{Fausto}

O que ela estudou?

\section{Kuper}

Matemática. Na universidade, ela se tornou muito amiga de Eileen Krige. Ela e seu marido, J. D. Krige, são os autores de um clássico da etnografia sulafricana, The Realm of a Rain Queen, sobre os Lovedu do Transvaal. Minha tia Hilda Kuper a conheceu. Quando Malinowski veio à África do Sul, antes de eu nascer, ele visitou a minha casa. Quando eu disse que queria me tornar antropólogo, minha mãe sabia bem do que se tratava e ficou realmente brava! Ela disse, "você está completamente louco!" O irmão de meu pai era Leo Kuper, um sociólogo muito famoso na África do Sul, e Hilda Kuper era sua esposa. Mas durante a guerra, quando eu era garoto, meu tio foi servir o exército no Norte da África e depois na Itália, e minha tia Hilda Kuper foi morar conosco, de modo que fiquei muito ligado a ela.

\section{Neiburg}

E como ela se tornou antropóloga?

\section{Kuper}

Não tenho certeza. Havia uma mulher que dava aulas de antropologia na Universidade de Witwatersrand, a primeira professora da área nessa universidade, chamada Agnes Winifred Hoernlé, nascida na África do Sul, em 1885. Ela estudou em Cambridge com Haddon e Rivers, depois em Leipzig com Wundt, e também por algum tempo com Durkheim em Paris. Casou-se com um alemão, professor de filosofia. Eles estavam em Harvard juntos quando ele adoeceu, e naquela época quando uma pessoa tinha problemas de pulmão, era mandada ou para a Austrália ou para a África do Sul. Então eles vieram para a África do Sul, a terra natal dela; ele se tornou professor de filosofia na universidade e ela fundou o departamento de antropologia; ela era uma professora extremamente carismática. A antropologia que ensinava era muito engajada politicamente, muito crítica em relação à política racial da África do Sul, e focalizava o que muitas pessoas identificavam como os novos problemas sociais, os problemas urbanos. Na universidade, não havia sociologia ou ciência política que valesse a pena, então para os jovens estudantes o que havia era essa professora carismática abordando algo que era relevante, que tinha interesse político. Esses estudantes eram bastante conscientes politicamente, era o momento da ascensão do fascismo na Europa e existia um sentimento de que havia o risco de surgir algum tipo de sistema fascista na África do Sul. Para esses estudantes, a antropologia da senhora Hoernlé era algo muito interessante, e acho que Hilda ficou atraída por isso. Ela na verdade não era sul-africana, ela viera da Rodésia para estudar. Na época, Schapera tinha acabado de voltar, ele havia sido o primeiro a ir estudar com Malinowski, e incentivou alguns outros. E nesse período, em torno de Malinowski muita coisa interessante estava acontecendo.

\section{Fausto}

Quem foram os primeiros antropólogos de origem sul-africana?

\section{Kuper}

Há o período inicial, com os missionários e administradores, alguns dos quais eram antropólogos de renome, como Henri Junod, que escreveu algumas et- 
nografias africanas clássicas e quando se aposentou do serviço missionário tornou-se professor de etnologia em Nêuchatel. Eram pessoas cuja expertise residia em um longo envolvimento na região, em conhecer muito bem a língua, muitas vezes escrevendo gramáticas e dicionários, bem como etnohistórias e etnografias. Mas a virada realmente extraordinária para a antropologia sulafricana ocorreu quando foi estabelecida a primeira cadeira de antropologia na Universidade da Cidade do Cabo, em 1921. Por uma série de casualidades, essa cadeira, em vez de ir para um sul-africano, foi ocupada por RadcliffeBrown, pioneiro da antropologia sociológica e comparativa. Ele veio e organizou o setor, voltando as costas para a antropologia sul-africana já estabelecida e tentando criar um discurso totalmente novo na África do Sul. RadcliffeBrown não procurou fazer isso apenas abstratamente, ele tentou estabelecer na África do Sul uma antropologia que abordasse os problemas sul-africanos, e acabou forçado a reconhecer o grande debate existente entre os segregacionistas e os anti-segregacionistas. Ele incorporou isso à sua antropologia, e uma das conseqüências, creio eu, foi que ele se tornou muito crítico em relação ao tipo de teoria da cultura que Malinowski e os antropólogos americanos estavam elaborando. Assim, a antropologia de língua inglesa feita na África do Sul esteve, desde o início, na linha de frente da antropologia britânica, desse tipo de antropologia internacional. Os melhores estudantes da primeira geração foram para a Inglaterra estudar com Malinowski e voltaram reforçando essas novas e instigantes idéias. Os anos dourados da antropologia sul-africana foram as décadas de 30 e 40, quando são publicadas as grandes monografias etnográficas, escritas por pessoas que es- tudaram na Inglaterra com os maiores nomes da antropologia e que depois voltaram; pessoas que se consideravam parte da revolução malinowskiana na antropologia. Assim, gente como Max Gluckman, Hilda Kuper, Monica Wilson, Ellen Helmen e outros mais fazem parte dessa antropologia muito modernista, dessa antropologia recém-profissionalizada. Mas com o triunfo do nacionalismo africânder depois da guerra, com a vitória do apartheid, e com a perda de posição política por parte das universidades de língua inglesa, essas pessoas ou seus descendentes deixaram a África do Sul. Com isso, a antropologia sul-africana de língua inglesa tendeu à estagnação depois dos anos 50 e 60.

\section{Fausto}

Algo que me impressiona é o fato de que no início dos anos 30 os seminários de Malinowski tinham mais ou menos vinte pessoas e cerca de um quarto desse total era de sul-africanos. Por que a África do Sul exportou tantos antropó$\log 0$ ?

\section{Kuper}

Porque na África do Sul a questão política é essencialmente uma questão de raça, etnicidade ou cultura, qualquer que seja a definição dada aos termos. Essas eram as questões políticas. Assim, pessoas politicamente conscientes, ou mesmo pessoas que quisessem fazer alguma coisa socialmente útil, se envolviam com a antropologia de uma maneira muito específica. No entanto, também era até certo ponto evidente que as questões presentes na África do Sul eram semelhantes a algumas das questões encontradas em outros territórios britânicos na África. Então havia esses dois aspectos no interesse pela África do Sul, que era vista como o exemplo mais avançado e complexo de um certo 
tipo de sociedade africana em processo de industrialização.

\section{Neiburg}

Isso provavelmente tem relação com a singularidade da África do Sul no contexto do Império Britânico.

\section{Kuper}

Bem, de onde mais vinham os antropólogos? A Austrália mandava antropólogos para a Grã-Bretanha, bem como a Nova Zelândia, e até certo ponto também o Canadá. Talvez a África do Sul mandasse mais gente, mas estava em uma posição semelhante. Nessas situações quase-coloniais, a pós-graduação ainda tinha que ser feita na metrópole, qualquer que fosse o campo.

\section{Neiburg}

Conte-nos um pouco sobre a sua mudança para a Inglaterra. Você completou sua formação básica em antropologia na África do Sul e depois foi para a Inglaterra fazer o Ph.D. Como foi essa experiência? Você já tinha estado na Inglaterra antes?

\section{Kuper}

Eu já tinha estado lá. Meu pai levounos, a mim e meu irmão, para passar um feriado na Inglaterra, ficamos cerca de uma semana. Mas eu sabia que teria de deixar a África do Sul em algum momento. Fui para a Inglaterra logo depois de uma série de ações extremamente repressivas empreendidas pelo governo nos anos 60. Houve um grande confronto em Sharpville, quando atiraram em negros desarmados; foi decretado estado de emergência, muitas pessoas foram presas sem julgamento por períodos indefinidos. Para muitos de nós tornou-se óbvio que a situação era desesperadora, e que ficar na África do Sul envolveria um compromisso político completo durante um prazo muito longo, e uma vida muito arriscada. Então decidi partir. Mas eu queria fazer a minha vida na África. Fui fazer o meu Ph.D. em Cambridge. Não obtive permissão para fazer pesquisa na África do Sul, mas consegui ir para Bechuanaland, que é vizinha à África do Sul. Quando terminei meu Ph.D., em 1966, casei-me, e minha mulher e eu voltamos para Bechuanaland. Depois fomos para Uganda, onde moramos durante três anos e meio, com minha mulher fazendo pesquisa para o seu Ph.D. e eu dando aulas na universidade. Eu teria permanecido em Uganda indefinidamente com muita satisfação, estava começando a fazer pesquisas por lá. Mas logo ficou evidente que a situação política era crítica, e de fato o golpe de Idi Amin aconteceu apenas alguns meses depois. Na ocasião, havia três ofertas de trabalho para antropólogos sociais: em Cingapura, em Hong Kong e no University College de Londres. Eu me inscrevi para as três, com a esperança de ir para Hong Kong, mas se isso não fosse possível, Cingapura também estaria bom. Mas só fui chamado para entrevista em Londres, fui selecionado para o cargo, e assim voltamos para Londres em 1970.

\section{Fausto}

Em qual faculdade (college) você estudou em Cambridge? Quem eram os seus colegas?

\section{Kuper}

Estudei no King's College. Os dois superiores do College, e do departamento, eram Meyer Fortes e Edmund Leach. Eu já contei várias vezes a história dos meus dois primeiros dias em Cambridge, até já a publiquei. No primeiro dia Edmund Leach me chamou para almoçar, e durante o almoço me disse (lembrem-se de que era um departamento muito pe- 
queno, tinha seis membros, e eu já sabia que havia duas facções): "veja bem, há dois grupos no departamento, há o meu grupo, no qual as pessoas trabalham na Ásia, e há o outro grupo, em que as pessoas trabalham na África. E quanto a você??" Eu respondi, "bem, eu vou trabalhar no sul da África". Assim acabou o interesse de Leach por mim, mas ele foi suficientemente educado para continuar a conversa. Ele disse, "deixe-me dizer-lhe algo sobre Cambridge. Meyer Fortes - que por sinal também era um judeu sul-africano - já está aqui há muitos anos, e é claro que ele sabe muita coisa sobre os Tallensi em Gana. Mas ele nunca conseguiu entender Cambridge. O que você precisa saber sobre Cambridge é o seguinte: é um lugar fundamentalmente de classe média baixa". Eu disse, "Muito obrigado." No dia seguinte, Meyer Fortes me convidou para almoçar, e disse: "Então você vai trabalhar na África? Onde?" Eu respondi: "Acho que no sul da África". Ele disse: "Então vá conversar com o Schapera em Londres". Disse ainda: "E deixe-me dizer-lhe algo sobre Cambridge. Edmund está aqui há muito tempo, é claro, mas ele nunca iria lhe dizer isso. Aliás é provável que ele nem saiba disso. O que você sempre precisa ter em mente a respeito de Cambridge é que eles não gostam de judeus". Ambas as afirmações eram verdadeiras e me foram úteis. Mas eu praticamente não aprendi antropologia em Cambridge, não havia orientação, nada. Você lia, e ia aos seminários, que eram palestras geralmente muito chatas. Depois, fiz meu trabalho de campo, escrevi minha tese, e obtive meu primeiro emprego. Foi aí que comecei a aprender antropologia, pois quando fui para Uganda, em 1967, eu precisei dar aulas de introdução à antropologia social. E eu não sabia nada sobre isso.

\section{Neiburg}

E quanto ao seu primeiro trabalho de campo, para o seu Ph.D.?

\section{Kuper}

Bem, meu primeiro e segundo trabalhos de campo foram feitos no Kalahari, junto a um grupo com o qual Schapera já havia tido contato, foi ele quem sugeriu que eu fosse para lá e os estudasse. Era uma região muito distante e isolada no deserto do Kalahari. Assim, estudei esse grupo para o meu Ph.D. e voltei para lá novamente por nove meses antes de ir para Uganda. Era um grupo de pastores de língua bantu, e eu tinha interesse no seu sistema político. No fundo, eu queria saber se, quando eu fosse ao encontro de alguma tribo sul-africana muito isolada, eu encontraria aquilo de que falavam os antropólogos africânderes, uma espécie de sociedade tribal viável, com um chefe, e assim por diante. Descobri que mesmo lá nessa área, tão isolada, a política da aldeia, a política tribal, estava completamente penetrada pela estrutura nacional, mesmo em um estado colonial tão enfraquecido como Bechuanaland. Em segundo lugar, descobri que a estrutura política da aldeia, longe de ser a chefia autoritária que os sul-africanos gostavam de imaginar, era na verdade a de uma sociedade extremamente anárquica, democrática, mal-organizada, porém aberta, muito tolerante em relação a críticas e desvios.

\section{Fausto}

Por isso você deu o título An African Democracy para o livro?1

\section{Kuper}

Sim. E fui criticado por isso porque as mulheres não tinham direitos políticos completos, e havia uma pequena minoria de servos bosquímanos, que eviden- 
temente eram excluídos do sistema. Isso tudo é realmente verdade, mas ainda assim, para os homens, e na realidade para a maioria das pessoas da aldeia, tratava-se de um sistema muito aberto e democrático. Eu voltei para Bechuanaland em parte porque em 1966 o país se tornou independente, com o nome de Botsuana, e eu queria ver que mudanças e conseqüências isso havia trazido no âmbito local. Assim, o meu livro se chama An African Democracy também no sentido de que Botsuana estava se tornando um Estado democrático e a aldeia estava se tornando um segmento de governo local dentro de um Estado democrático independente.

\section{Neiburg}

Como você começou a pesquisar a história da antropologia britânica?

\section{Kuper}

Foi algo completamente acidental. Quando voltei para a Inglaterra em 1970, retomei minha amizade com Schapera, que já estava aposentado. Ele estava editando uma série de textos introdutórios à antropologia para a editora Penguin. Eu não sei nem por que ele teve a idéia, nem por que me convidou para escrever um livro para essa série, tratando da história da antropologia britânica ${ }^{2}$. De qualquer maneira, era uma idéia absurda. Eu tinha trinta anos, era inexperiente, por que ele iria me pedir para escrever esse livro sobre um tema a respeito do qual eu nunca fizera nenhuma pesquisa, não tinha nenhuma publicação, nem mesmo havia pensado sobre o assunto? Mas eu disse que sim, principalmente porque eu precisava do dinheiro. Então, escrevi esse livro, trabalhando durante a noite, li tudo que pude encontrar. Nessa época não havia arquivos, a coleção de Malinowski, que era o principal arquivo, es- tava sendo organizada por Firth, e ele me negou acesso, porque o arquivo ainda não estava aberto. Ele também se recusou a ser entrevistado por mim, mas alguns dos outros me concederam entrevistas; quase tudo mentiras e fantasias e propaganda, a não ser por Lucy Mair que me deu uma entrevista totalmente honesta. Mas havia uma quantidade suficiente de textos publicados, de modo que pude produzir uma espécie de história. Assim, escrevi esse pequeno livro, que foi publicado quando eu estava em campo na Jamaica. E de repente começaram a me chegar resenhas histéricas. O Times Literary Supplement, que na época preservava o anonimato de seus resenhistas, publicou resenhas anônimas de três páginas: três páginas insultando o livro. Eu estava na Jamai$\mathrm{ca}$, recebendo essas coisas, sem saber o que estava acontecendo na Inglaterra. Foi horrível, mas por outro lado o livro estava vendendo muito bem.

\section{Fausto}

Ambos os grupos, ou seja, os estruturais-funcionalistas e os de orientação mais malinowskiana, tiveram o mesmo tipo de reação?

\section{Kuper}

Todos ficaram muito incomodados. É preciso lembrar que a Inglaterra de então ainda era muito hierárquica e conservadora. Isso foi no final de 1967. Os professores de antropologia eram muito poucos, havia talvez sessenta ou setenta antropólogos, e todos se conheciam. Os professores eram homens muito, muito poderosos, verdadeiros barões. Max Gluckman, Firth, Evans-Pritchard, Meyer Fortes, eram grandes figuras, personalidades fortes, muito importantes e muito conscientes de sua própria importância. E todos pensavam que quando se aposentassem, iriam escre- 
ver a história da antropologia britânica. Algo que explicasse a antropologia, explicasse como tudo levava a eles (ou pelo menos à sua escola). E de repente vem esse joão-ninguém, esse rapazinho, que direito tem ele de escrever a história da antropologia? E além de tudo cheia de críticas a eles! Alguns ficaram incomodados apenas porque eu dei mais espaço para tal ou qual pessoa do que para eles. Ou porque deixei de mencionar o que consideravam a sua contribuição mais importante. De modo que eu nunca poderia ter feito a coisa certa. Enfim, todos odiaram o livro, o que mostra quão ignorante eu era; eu sequer pensava que o livro causaria essas reações histéricas.

\section{Fausto}

Mas mesmo Meyer Fortes reagiu assim?

\section{Kuper}

Não. É claro que é diferente quando você conhece alguém e tem um envolvimento. Mas outros, como Max Gluckman, ficaram horrorizados. Escreveram-me várias cartas extremamente críticas e ofensivas. Foi uma reação surpreendente.

\section{Fausto}

E Mary Douglas, que nessa época estava no University College?

\section{Kuper}

Ela é minha amiga. E no University College estava acontecendo outra coisa. Mais ou menos nessa mesma época, quando eu voltei da Jamaica, em 1974, surgiu subitamente um cargo cult marxista na antropologia, na universidade. Todos os velhos livros deviam ser queimados, talvez junto com os velhos professores, e um novo mundo iria surgir, com uma nova antropologia na qual todos seriam iguais e livres e os impérios iriam se dissolver. Isso tudo era muito excitante, os jovens professores e estudantes de antropologia lendo Althusser e aqueles textos todos na hora do almoço. Era como sessões de leitura da Bíblia, sessões coletivas, nas quais todos tinham que participar. Havia apenas duas pessoas no departamento que não se impressionavam com isso tudo, Mary Douglas e eu. E nós sofremos muitas pressões por parte dos estudantes e dos jovens professores ativistas. Assim, nós nos apoiávamos mutuamente e desenvolvemos um certo tipo de solidariedade.

\section{Neiburg}

Como você vê, em termos teóricos, a relação entre a sua produção em história da antropologia, que começa com Anthropology and Anthropologists, e seus trabalhos mais empíricos, baseados em pesquisa de campo?

\section{Kuper}

Eu não tenho certeza de que haja alguma relação estreita ou necessária entre as duas coisas, além de uma relação acidental e biográfica. Mas o fato de fazer ambos os tipos de pesquisa evidentemente significa que elas se influenciam mutuamente. Assim, por exemplo, eu escrevi um livro chamado Wives for Cattle, que era um estudo comparativo de sistemas tradicionais de parentesco do sul da África ${ }^{3}$. Uma das coisas que me intrigava era o problema da teoria da linhagem; eu percebi que ela era empiricamente inútil naquele contexto e decidi dizer: "No sul da África a teoria da linhagem é inútil". Mas ao mesmo tempo, e aí está outra casualidade, recebi um convite do Annual Review of Anthropology para escrever um artigo sobre a teoria da linhagem. Mais uma vez, não sei por que Meyer Fortes me indicou. E decidi tratar do tema histori- 
camente. Abordar o tema historicamente foi também uma maneira de entender por que essa teoria não era útil, e por que havia sido tão influente. De onde ela veio? Quais conexões estabelece? Esse artigo deu origem a um livro chamado The Invention of Primitive Society $^{4}$. Suponho que um antropólogo padrão, que estivesse escrevendo, por exemplo, sobre etnografia comparativa, e se deparasse com o problema da teoria da linhagem, talvez escrevesse uma crítica teórica da teoria da linhagem. A minha peculiaridade intelectual é que quando eu começo a pensar sobre essas questões teóricas, tendo a formulá-las, em parte, em termos históricos. É o que voltou a me acontecer agora com a questão da "cultura". Eu não queria escrever um estudo histórico, mas estava incomodado com a questão da cultura, que naquele momento parecia muito influente em vários debates antropológicos nos Estados Unidos e também na Grã-Bretanha. Por várias razões empíricas e políticas, era algo que me parecia inaceitável. Em função da minha formação na África do Sul, eu não gostava desse tipo de teoria. E para tentar entender de que tratava essa teoria, o que ela tinha de certo e o que tinha de errado, a maneira que me parecia mais óbvia era situá-la historicamente. Para mim, portanto, as questões teóricas que vão surgindo demandam algum tipo de tratamento histórico. E essas questões teóricas surgem porque estou preocupado com respostas que estão sendo dadas a questões etnográficas ou de antropologia comparativa. Eu não me vejo como historiador, sou alguém que pensa em termos históricos a respeito de questões teóricas da antropologia.

\section{Neiburg}

Vamos voltar ao trabalho de campo. Como você acabou indo para a Jamaica?

\section{Kuper}

Veja bem, tudo isso que estou contando é uma série de casualidades.

\section{Neiburg}

Possivelmente é assim para todos nós, a questão é como transformar essas casualidades em problemas e questões.

\section{Kuper}

Ótimo, mas não me peçam para racionalizar isso tudo retrospectivamente como uma série de decisões lógicas e coerentes. Quando morávamos em Uganda, minha esposa fez trabalho de campo para o seu Ph.D. com a comunidade goense que existia na África Oriental. Nós nos interessamos muito por essa comunidade e pedimos uma bolsa para irmos juntos a Goa fazer trabalho de campo. Conseguimos a bolsa, mas o governo indiano estava naquele momento em guerra com o Paquistão e havia alguns problemas em Goa, e eles estavam muito relutantes em nos permitirem acesso. O meu chefe de departamento, M.G. Smith, era jamaicano. Na Jamaica, havia um governo recém-eleito, presidido por Michael Manley, um governo levemente radical. Smith era um velho amigo de Manley, e Manley pediu-lhe que assumisse boa parte da pesquisa social. Então Smith me disse: "Veja bem, já ficou claro que os indianos não vão deixar vocês entrarem, você vai acabar perdendo o seu ano sabático. Vou contratá-lo para fazer pesquisa na Jamaica". Como sempre digo, assim como Cristóvão Colombo, eu estava procurando a Índia e fui parar na Jamaica. Mas não sabia nada sobre o Caribe. Nós havíamos nos preparado para fazer pesquisa em Goa. Eu li apenas algumas coisas e fui para a Jamaica, onde fiz um ano de trabalho de campo em diferentes regiões. Escrevi então um livro criticando a antropologia caribenha 
estabelecida, que falava de uma sociedade plural feita de diferentes cores, classes, e assim por diante 5 . Isso me parecia uma imagem completamente falsa do que eu estava verificando empiricamente. Escrevi esse livro sobre a Jamaica no qual previ, ainda que não com suficiente firmeza, que a Jamaica continuaria a ser uma democracia bipartidária. Naquela época as pessoas diziam que haveria um golpe, que surgiria um Estado com partido único. E eu achava que observando a estrutura dos partidos e a profundidade do apoio a eles, ficava claro que o país estava dividido com bastante equilíbrio, em todos os níveis, entre esses dois partidos que estavam fortemente institucionalizados nas aldeias.

\section{Fausto}

Eu gostaria de saber como você organizou seu trabalho de campo na Jamaica. Deve ter sido algo muito diferente de estudar uma aldeia no deserto do Kalahari, pois você disse que estudou a Jamaica como um país. É claro que se trata de uma pequena ilha, mas mesmo $\operatorname{assim...}$

\section{Kuper}

Bem, de fato é uma pequena ilha que tinha na época dois milhões de habitantes. Eu tive que optar entre me ligar à faculdade de ciências sociais da universidade ou à Agência Nacional de Planejamento, que era ligada ao gabinete do primeiro-ministro. Optei por esta última, pois através dela eu teria acesso fácil a tudo o que eu queria estudar. Eles também me prometeram, e cumpriram a promessa, assegurar total liberdade editorial. Eu lhes perguntei "Em que vocês estão interessados?" E eles me apresentaram uma questão muito geral: na Jamaica, cerca de um quarto da população vivia em Kingston, a principal cidade, que tinha uma taxa de desemprego muito alta e favelas muito precárias. Mesmo assim, as pessoas não paravam de chegar em Kingston vindas dos campos, ao mesmo tempo que os grandes empregadores na área rural reclamavam da falta de mão-deobra. A questão era saber o que estava acontecendo, e se haveria alguma maneira de transformar essa situação, estabilizando a migração. Para responder a essas questões, trabalhei alguns meses em uma área em Kingston, uma espécie de favela; alguns meses em uma pequena aldeia rural voltada para o comércio, perto de uma cidade comercial do interior, no meio das montanhas e bem distante de Kingston; mais alguns meses no litoral, em uma área de turismo, e, por fim, um mês em uma fazenda de cana-de-açúcar. Eu tinha acesso também às estatísticas do governo sobre emprego e agricultura. Acabei produzindo uma análise em termos de padrões de posse e herança da terra, e padrões de emprego nas plantações de cana. Fiz também uma análise dos diferentes padrões de emprego em Kingston, seja dos migrantes de origem rural, seja daqueles nascidos em Kingston. Essa análise mostrou que os migrantes de origem rural, apesar de ganharem muito pouco, ainda conseguiam empregos em Kingston, mesmo que temporários, já que eles aceitavam tarefas que os nascidos em Kingston, que participavam da economia "informal", não estavam dispostos a aceitar. Assim, tendo entendido os mecanismos reais que estavam em jogo na situação, o padrão se mostrava bastante racional. Mas ao fazer a pesquisa, descobri outras coisas também. O que mais me interessou surgiu logo no início, quando nos mudamos de Kingston para a área rural, e ficamos vivendo em uma pequena vila. Eu comecei a andar pelo povoado, a freqüentar os bares, mas ninguém falava comigo, 
com exceção de uma mulher de classe alta. Era bem deprimente. Fiquei uma semana lá e no domingo subi a serra e fui até o povoado seguinte. Assim que cheguei, todos vieram falar comigo, absolutamente eufóricos, e depois passaram a me visitar, a ir até minha casa para beber e jantar. Finalmente me explicaram aquela situação: todos sabiam que eu era do governo, da Agência Nacional de Planejamento, e todos supunham que eu apoiava Manley e era membro do People's National Party. A primeira vila era quase toda de oposição, ligada ao Jamaica Labour Party. Mas assim que subi a serra, entrei na vila que apoiava o governo e o People's National Party, que me consideravam um deles e logo vieram falar comigo. Descobri então que a área rural inteira era como uma colcha de retalhos: se uma vila era ligada ao PNP, a próxima seria ligada ao JLP, depois PNP, JLP, PNP, JLP, e assim por diante, porque se um povoado era de um partido, o povoado rival tinha que ser do outro. A mesma coisa acontecia nas favelas de Kingston - uma era de um partido, a outra era do outro. Era algo extraordinariamente estruturado.

\section{Neiburg}

Depois da Jamaica você foi para a Holanda?

\section{Kuper}

Sim, cerca de dois anos mais tarde. Havia um grande departamento de antropologia, especializado principalmente em Indonésia. Havia uma certa tradição de antropologia africana lá, então me convidaram para que consolidasse isso um pouco mais. Foi lá que escrevi meu livro Wives for Cattle, trabalhando principalmente sobre material histórico da África do Sul. Eu também fiz um trabalho de campo muito breve com al- guns alunos, nas Ilhas Maurício. Tornei-me um professor holandês; era uma vida agradável de cidade pequena. Depois, fui convidado a passar um ano em Stanford, no Center for Advanced Studies in Behavioral Sciences. Foi um ano maravilhoso, 1981. Encontrei todo tipo de pessoas, e percebi que estava me tornando provinciano; minha mulher decidiu que deveríamos voltar para Londres.

\section{Fausto}

Wives for Cattle é o último livro em que você trabalhou diretamente com materiais da África Meridional?

\section{Kuper}

Depois disso, publiquei vários artigos, principalmente artigos históricos sobre a África do Sul pré-colonial. Primeiro, em South Africa and the Anthropologist, e depois, mais recentemente, reuni alguns ensaios que foram publicados, no mês passado, em um livro chamado Among the Anthropologists ${ }^{6}$. Mas acho que não se trata tanto de estar me distanciando da África do Sul; o que está ocorrendo mais recentemente é que estou transitando de estudos mais etnográficos para estudos mais teóricos e históricos. Ainda assim, estou começando um projeto comparativo junto com alguns amigos na Europa, abordando as empresas familiares.

\section{Neiburg}

Sobre o que é esse estudo?

\section{Kuper}

O paradoxo é o seguinte: as pessoas imaginam uma moderna sociedade de mercado capitalista, em que as empresas são extremamente racionais. Mas, na realidade, se observarmos a maioria das sociedades européias, entre 85\% e $95 \%$ das empresas são familiares. Isso é muito inesperado, dada toda a teoria a 
respeito da natureza do mercado e do funcionamento do capitalismo. E não são apenas as empresas menores - há empresas como a Fiat e a Olivetti, na Inglaterra temos alguns dos maiores bancos, grandes empresas e assim por diante. Mesmo nos Estados Unidos, mais de $80 \%$ de todas as empresas são familiares. Claro que muitas delas são pequenas lojas. Essas empresas familiares fazem com que se tenha que pensar de maneira diferente sobre o capitalismo. Se consultarmos a literatura sobre empresas familiares, veremos que é quase toda produzida pelas escolas de administração de empresas. Os especialistas dessas escolas desenvolveram estudos de caso dessas empresas e de alguns dos problemas que elas encontram tais como a sucessão, a capacitação da nova geração, as dificuldades para levantar capitais, e coisas assim. Em outras palavras, as empresas familiares são apresentadas como um amontoado de problemas, porque elas não se adequam a uma idéia abstrata do capitalismo. Assim, o conselho que dão às empresas familiares é que elas se tornem mais parecidas com as empresas comuns. Mas se colocarmos questões antropológicas, então é possível começar a pensar: por que mais de $85 \%$ das empresas são familiares? Se você adotar uma visão darwinista, elas são mais bem-sucedidas, pois sobrevivem. Então devem estar fazendo alguma coisa melhor do que os outros tipos de empresas. E, darwinianamente falando, quais são as vantagens que elas apresentam? Evidentemente, é algum tipo de confiança, que é construída com base em uma ética de parentesco, e que depende de ter um tipo de economia dentro da empresa que é diferente daquela fora dela. A economia dentro da empresa é de serviços mútuos. Em algumas delas você descobre que mesmo para os trabalha- dores é um negócio familiar, já que membros de uma mesma família trabalham na companhia. Torna-se possível questionar se se trata de uma economia capitalista, ou uma economia do dom, ou uma economia do parentesco, dentro do sistema capitalista, não na sua periferia, mas no coração do sistema. E isso nos leva a pensar sobre o parentesco de uma maneira diferente, porque se há uma empresa familiar, isso vai afetar as relações familiares, o casamento, vai afetar todas essas coisas internas à família.

\section{Neiburg}

Como você começou a conceber o livro sobre a cultura $?^{7}$ É um livro centrado na antropologia americana. Você poderia nos falar sobre a sua relação com a antropologia americana?

\section{Kuper}

Foi só quando o movimento pós-moderno deslanchou que eu senti que havia um grande movimento na antropologia americana que eu considerava muito perigoso para o desenvolvimento da antropologia nos Estados Unidos, e também internacionalmente; algo extremamente destrutivo diante daquela antropologia que reputo importante, baseada em pesquisas sérias, empíricas, comparativas, abordando questões de grande importância teórica e interesse público. Tudo isso estava sendo jogado fora por um tipo de relativismo realmente superficial e extremado, de caráter muito adolescente. Tratava-se, por assim dizer, de um novo cargo cult depois do marxismo, porém pior, mais destrutivo, que foi insidiosamente tornando-se cada vez mais poderoso na Europa. Na Inglaterra, muitos dos maiores antropólogos foram inteiramente cativados por esse movimento. Qualquer um que fizesse outro tipo de antropologia era 
considerado um obstáculo ao progresso, da mesma maneira que havia ocorrido naquele outro cargo cult. Então, comecei a procurar aliados, pessoas que, como eu, estavam desencantadas com isso tudo e sentiam que era necessário dar uma sustentação a uma antropologia sociológica, comparativa, uma antropologia mais positivista. Encontrei essas pessoas por toda a Europa, e esse foi um dos impulsos para a criação da European Association of Social Anthropologists (EASA). Isso deu a impressão, para algumas pessoas nos Estados Unidos, de que se tratava de um movimento antiamericano, o que não é verdade. Eu estava me contrapondo a um movimento específico dentro da antropologia americana, o que é outra coisa.

\section{Neiburg}

Quando você foi para o Institute of Advanced Studies de Princeton, em 1994/ 95, você já tinha o projeto do livro?

\section{Kuper}

Eu já fui para Princeton com essa idéia. Geertz havia me convidado e eu fui para lá. Mas eu não tinha certeza de que seria viável. O que eu queria fazer era uma crítica histórica do desenvolvimento e dos usos dessa idéia de cultura, especialmente na antropologia norte-americana, mas também mais amplamente. Depois de quatro ou cinco meses lá, senti que era impossível, que eu não conseguiria organizar todo aquele material. Então subitamente vi uma estrutura para a primeira parte do argumento. E com a estrutura em mente, e tendo feito muitas leituras e anotações, eu simplesmente sentava todo dia pela manhã e escrevia; ao final de dez dias eu havia escrito cerca de cem páginas. Foi uma experiência estranha para mim, eu nunca tinha tido essa experiência de ver um livro surgir repentinamente.

\section{Fausto}

Foi como se você estivesse escrevendo o lado americano do Anthropology and Anthropologists.

\section{Kuper}

Mas dessa vez eu sabia de antemão que se tratava de uma crítica, um ataque. Já Anthropology and Anthropologists não era um ataque à antropologia britânica.

\section{Neiburg}

Eu gostaria de entender a relação, se houver, entre a sua experiência como editor de Current Anthropology e o livro sobre cultura que você acaba de publicar.

\section{Kuper}

Bem, trata-se mais uma vez de uma casualidade. Eu logo descobri que Current Anthropology tem um espaço intelectual muito específico. Em primeiro lugar, é o único periódico realmente internacional na área de antropologia. Ainda que seja obviamente dominado pelos americanos, sempre teve como política buscar uma lista de colaboradores e leitores tão internacional quanto possível. Em segundo lugar, era o único grande periódico antropológico que ainda estava estruturado no modelo de quatro campos e baseado em um modelo de tipo evolucionista. Eu fui gradualmente me interessando por essas questões evolucionistas, que não tiveram nenhum peso em minha formação intelectual e na antropologia britânica e européia. Nessa época, estavam ocorrendo desenvolvimentos muito interessantes nos estudos sobre o Neanderthal, realizados na Europa, e também em vários outros tipos de estudos evolucionários. Eu tive a oportunidade de me encontrar com algumas das pessoas mais interessantes nesse campo, e me entusiasmei pelo que eles estavam fazendo. 
Então escrevi um livro para o público geral, de divulgação, um tipo de antropologia darwinista ${ }^{8}$. A parte intelectual do trabalho como editor de Current Anthropology foi elaborar o material para esse livro. A outra coisa que aprendi com essa experiência foi que pela primeira vez estive realmente em contato com a antropologia do mundo inteiro. E comecei a pensar no futuro da antropologia como algo que não seria ditado por uma metrópole, mas que resultaria de um debate realmente cosmopolita. Passei a me interessar mais pelas inovações que estavam surgindo em outros lugares.

\section{Fausto}

Deixe-me fazer uma pergunta muito geral, sem nenhuma intenção biográfica: com relação à antropologia que está sendo produzida agora, qual é a que você gosta? Ou seja, se você tivesse que escolher alguns livros que andou lendo e que admira, o que você sugeriria?

\section{Kuper}

Bem, eu andei lendo alguns dos trabalhos produzidos aqui no Museu. Esse é um bom exemplo da antropologia que eu gosto. É empírica, envolvida com o contexto social e político, tem uma sofisticação crítica, conhece diversos modelos e abordagens teóricas sem ser dogmática ou fechada em relação a algum deles. Toma conhecimento dos outros trabalhos que estão sendo desenvolvidos na mesma área a partir de outras tradições, e aborda essas outras pesquisas de maneira respeitosa, porém crítica, de maneira aberta. É esse tipo de antropologia que eu gosto. A antropologia da qual não gosto é a do tipo extremamente relativista e antiempírica, por razões que eu expliquei ad nauseam em outros lugares, e também o tipo de antropologia ideológica cuja agenda é definida por questões ideológicas - feminismo, nacionalismo étnico ou qualquer outra. Eu diria que gosto de uma antropologia que seja racional, humana, e sofisticada. Algo que eu chamaria de antropologia cosmopolita.

\section{Neiburg}

Quando nos contou sobre sua mudança para a Inglaterra, você comentou que queria fazer sua vida na África. Qual o significado dessa afirmação hoje para você?

\section{Kuper}

Quando ocorreu a transição na África do Sul, no final dos anos 80, convidaram-me para assumir cargos muito bons na África do Sul, em algumas das principais universidades, e eu fiquei louco para ir. Mas minha mulher se recusou dizendo: "nossos filhos cresceram na Europa, eles não vão se mudar para lá, eles vão querer construir suas vidas aqui na Inglaterra. Eu não quero estar vivendo lá enquanto meus filhos, e talvez algum dia meus netos, estão aqui na Europa. Eles estão aqui, foi aqui que nós vivemos, e é aqui que ficaremos. Então nada feito." Eu fiquei muito desapontado, mas evidentemente consegui entender a lógica da argumentação, pude compreender e dar valor ao que ela dizia. Era verdade, e foi apenas naquele momento que percebi que nós havíamos vivido como muitos imigrantes, cultivando essa fantasia da volta. E quando a oportunidade finalmente apareceu e eu poderia ter voltado, já era tarde demais. Eu já não podia mais. Foi um momento muito difícil para mim, porque eu sempre vi a mim mesmo como sul-africano, não como inglês. Eu precisei entender, como muitos imigrantes, que na realidade eu havia me tornado outra coisa.

Transcrição e edição revistas por Adam Kuper Tradução: John Comerford 


\section{Notas}

1 Kalahari Village Politics: An African Democracy. Cambridge: Cambridge University Press, 1970.

2 Anthropologists and Anthropology: The British School, 1922-1972. London: Alan Lane (Penguin). Após os direitos de publicação serem cedidos para Routledge, o título foi invertido para Anthropology and Anthropologists, 1973.

3 Wives for Cattle: Bridewealth and Marriage in Southern Africa. London: Routledge \& Kegan Paul, 1982.

4 The Invention of Primitive Society: Transformations of an Illusion. London: Routledge, 1988.

5 Changing Jamaica. London: Routledge \& Kegan Paul, 1976.

6 South Africa and the Anthropologist. London: Routledge, 1987; Among the Anthropologists. London: Athlone Press, 1999.

7 Culture: The Anthropologists'Account. Cambridge, Ma.: Harvard University Press, 1999.

8 The Chosen Primate: Human Nature and Cultural Diversity. Cambridge, Ma.: Harvard University Press, 1994. 